Revista Brasil. Bot., V.29, n.1, p.183-186, jan.-mar. 2006

\title{
Occurrence of the rare genus Microcrocis P. Richter (Chroococcales, Cyanobacteria) in a coastal lagoon from southern Brazil
}

\author{
VERA REGINA WERNER ${ }^{1,3}$ and CÉLIA LEITE SANT' ANNA ${ }^{2}$
}

(received: April 20, 2005; accepted: February 9, 2006)

\begin{abstract}
Occurrence of the rare genus Microcrocis P. Richter (Chroococcales, Cyanobacteria) in a coastal lagoon from southern Brazil). The paper records the first occurrence of the genus Microcrocis P. Richter (Chroococcales, Cyanobacteria), represented by M. pulchella (Buell) Geitler, in Brazil. The species was found in two zones, one with freshwater and the other with brackish water, of a coastal lagoon of Rio Grande do Sul State (31 $15^{\prime}-31^{\circ} 30^{\prime} \mathrm{S}$ and 5054'-51 $09^{\prime}$ 'W). Comparison between M. pulchella and its most closely related species is presented. Up to now this species had occurrence records limited to freshwater systems in temperate regions. Its presence in a subtropical coastal lagoon from southernmost Brazil, either in fresh or in brackish water, broadened the knowledge of the distribution area of M. pulchella.
\end{abstract}

Key words - Brazil, coastal lagoon, Cyanobacteria, Microcrocis

RESUMO - (Ocorrência do raro gênero Microcrocis P. Richter (Chroococcales, Cyanobacteria) em uma lagoa costeira do Sul do Brasil). O trabalho apresenta o primeiro registro de ocorrência do gênero Microcrocis P. Richter (Chroococcales, Cyanobacteria), representado pela espécie M. pulchella (Buell) Geitler, no Brasil. A espécie foi encontrada em zona de água doce e salobra de uma lagoa costeira do Estado do Rio Grande do Sul (31 $15^{\prime}-31^{\circ} 30^{\prime} \mathrm{S}$ and $\left.50^{\circ} 54^{\prime}-51^{\circ} 09^{\prime} \mathrm{W}\right)$. É apresentada comparação entre $M$. pulchella e suas espécies próximas. Até o momento, a espécie apresentava registro de ocorrência limitada a ambiente de água doce de zona temperada. Sua presença em uma lagoa costeira subtropical, no extremo Sul do Brasil, tanto em água doce como salobra, amplia a área de distribuição conhecida de M. pulchella.

Palavras-chave - Brasil, Cyanobacteria, lagoa costeira, Microcrocis

\section{Introduction}

Microcrocis P. Richter was proposed by Richter (1892) based on material collected in a ditch near Leipzig (Germany), characterized essentially by its flat, tabular colonies, composed by one layer of packed cells, arranged in regular or irregular rows. Fott (1972) considered the taxonomy of Microcrocis species confusing, and their occurrence rather rare in comparison with the nearest genus Merismopedia. Microcrocis species were initially classified by Lagerheim (1883) as section Holopedium of the genus Merismopedia. On the other hand, in 1893, the same author elevated the section Holopedium to genus level. Frémy (1930) and Geitler (1932) also considered Holopedia as an independent genus, whereas Geitler (1942) considered it synonymous of the genus Microcrocis. Komárek \& Anagnostidis (1999) also followed the synonymyzation proposed by Geitler (1942)

\footnotetext{
1. Fundação Zoobotânica do Rio Grande do Sul, Museu de Ciências Naturais, Caixa Postal 1188, 90001-970 Porto Alegre, RS, Brasil.

2. Instituto de Botânica, Seção de Ficologia, Caixa Postal 4005, 01061-970 São Paulo, SP, Brasil.

3. Corresponding author: vrwerner@fzb.rs.gov.br
}

and considered Microcrocis as a member of the family Merismopediaceae, sub-family Merismopedioideae.

Komárek \& Anagnostidis (1999) stated that Microcrocis comprises ten well defined species and listed four others that should be revised. Most species have been found in European and North American freshwater bodies. For the first time, the genus, represented by $M$. pulchella (Buell) Geitler, is recorded in a Brazilian water system. It was originally found in a lake in Minneapolis, Minnesota. Up to now, M. geminata, as Holopedia geminata Lagerheim, was the only species of Microcrocis reported for South America (Argentina, Tierra del Fuego) by Guarrera (1986).

The present paper registers the occurrence of M. pulchella specimens in "Peixe" Lagoon, a subtropical, coastal lagoon from southern Brazil. This paper aims to contribute to the taxonomy, ecology, and geographic distribution of the genus Microcrocis.

\section{Material and methods}

Study area - "Peixe" Lagoon is a very peculiar ecosystem, situated in the southern region of the Coastal Plain of Rio Grande do Sul State, Brazil, in a narrow zone between the Atlantic Ocean and Patos Lagoon ( $31^{\circ} 15^{\prime}-31^{\circ} 30^{\prime} \mathrm{S}$ and 50 54'- 
$\left.51^{\circ} 09^{\prime} \mathrm{W}\right), 1.5$ to $3 \mathrm{~km}$ from the ocean. It is a closed system during most part of the year, being supplied essentially by rain water and, occasionally, by the sea through a canal, which periodically connects the lagoon to the sea (figure 1). It belongs to the "Peixe" Lagoon National Park.

The lagoon is approximately $40 \mathrm{~km}$ long and $1 \mathrm{~km}$ wide. Its surface area is $43.70 \mathrm{~km}^{2}$, the volume is $12.6710^{6} \mathrm{~m}^{3}$, and the average depth is $29 \mathrm{~cm}$ (Schwarzbold \& Schäfer 1984). During the phycoflora investigation at different sites of the lagoon, from December 1990 to December 1992, the maximum and minimum depth registered were $1 \mathrm{~m}$ and $15 \mathrm{~cm}$, respectively; $\mathrm{pH}$ ranged from 6.2 to 8.4 , water temperature from 21 to $26{ }^{\circ} \mathrm{C}$, and the salinity varied at the different sites. Low salinity values $(0 \%-0.8 \%$ ) have only been reported in the northernmost portion of the lagoon, and in the other zones, the salinity oscillated from $14 \%$ o to $51 \%$ o (V.R. Werner, unpublished data). The lagoon is subject to high evaporation due to its shallowness, and during very dry periods, most of its area dries completely. The presence of grasses, inside and around the lagoon, indicates the variation of water levels (Chomenko 1981). The algal community of "Peixe" Lagoon is rich, composed essentially of diatoms and cyanobacteria.

The studied specimens were collected in December 1990 from two sites of "Peixe" Lagoon: one in a freshwater and the other in a brackish water zone. The samples were collected using a $25 \mu \mathrm{m}$ mesh plankton net. All samples were preserved

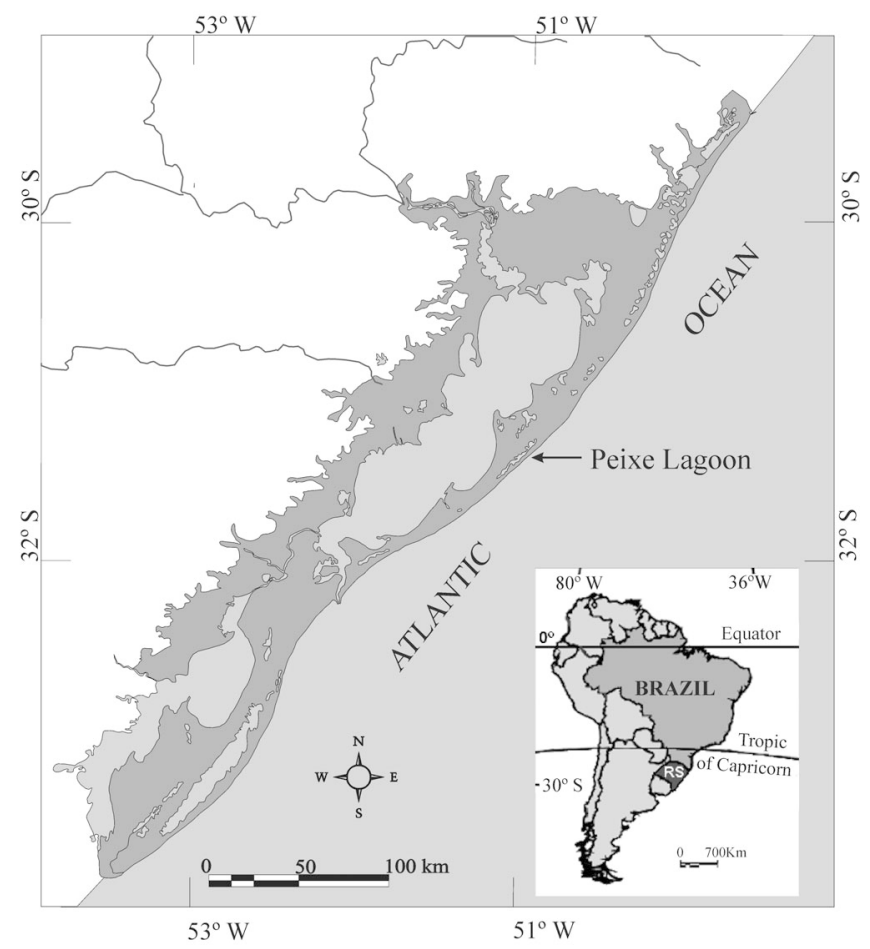

Figure 1. Map of the coastal lagoon system of Rio Grande do Sul State, Brazil, showing the "Peixe" Lagoon. in a $4 \%$ formaldehyde solution and incorporated to the "Prof. Dr. Alarich R. H. Schultz " Herbarium (HAS), Porto Alegre, Rio Grande do Sul State, Brazil, under the numbers 25775 and 25784. The classification system of Komárek \& Anagnostidis (1999) was adopted.

\section{Results and Discussion}

Microcrocis P. Richter is characterized by developing microscopic to macroscopic, flat, tabular and mucilaginous colonies, composed of one layer of densely packed cells, sometimes forming sub-colonies; cells elongated, ellipsoidal, oval, rod-shaped or polygonal, without mucilaginous envelope, oriented with their longer axis perpendicular to the plane of the colony, irregularly arranged, sometimes disposed in perpendicular rows in young colonies; cellular division in two perpendicular planes in successive generations; cells separate and slightly shift apart from one another after division; reproduction by disintegration of colonies.

Microcrocis differs from the nearest genus Merismopedia by the elongated cells oriented by their longer axis perpendicular to the plane of the colony, whereas in Merismopedia the cells are spherical or widely elliptical, after the division they are hemispherical, and arranged with their longer axis in the colony plane. In addition, the cells are disposed in perpendicular rows forming square or rectangular colonies in Merismopedia, whereas in Microcrocis they are irregularly arranged, especially in old colonies. In several species, rows of cells are rarely formed, and the colonies usually present irregular outlines.

For the first time, the genus, represented by $M$. pulchella, is registered in a Brazilian water body. This is also the first record of the species in South America and the second in the world.

Microcrocis pulchella (Buell) Geitler in Engler \& Prantl, Natürl. Planzenfam., 2ed., 1b:56. 1942.

Basionym: Holopedia pulchella Buell, Bull. Torrey bot. Club 65:385. 1938.

Figures 2-4

Colonies flat, tabular, elongated, and irregular, $72-85.8 \times 50-70.6 \mu \mathrm{m}$, composed by many cells (ca. 300 ), densely and irregularly arranged; mucilage homogeneous, hyaline, diffluent; cells polygonal in apical view, elongated or oval at the periphery of the colonies, becoming hemispherical after division, 3.2-5.6 $\times$ (2-)2.3-3.6 $\mu \mathrm{m}$; cells elongated in lateral view, 3.8-6 $\mu \mathrm{m}$ long; cell content bright blue-green, homogeneous, without aerotopes. 


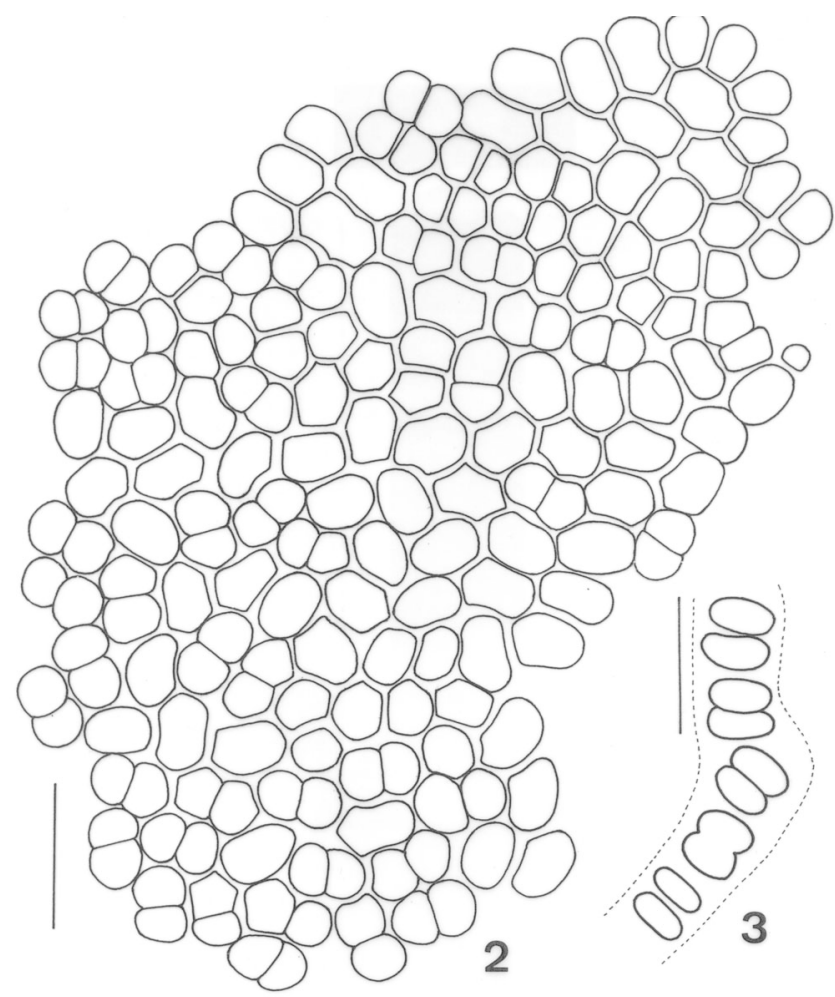

Figures 2-3. Microcrocis pulchella (Buell) Geitler. 2. Colony in apical view. 3. Cells in lateral view. Bars $=10 \mu \mathrm{m}$.

Microcrocis pulchella was originally described as Holopedia pulchella by Buell (1938), observed growing on mud in the inner part of a cyanobacterial mass, later floating to the surface of a deep (3-6 m) freshwater North American lake (Minneapolis, Minnesota), usually followed by the cyanobacterias Microcrocis geminata (Lagerheim) Geitler and Merismopedia convoluta Brébisson.

In "Peixe" Lagoon, it was found free-floating in the water, and also as an epiphyte of Merismopedia convoluta colonies, and on suspended material. Considering that the specimens were collected in this shallow lagoon (in sites with $15-40 \mathrm{~cm}$ depth) and with the presence of benthic algae, we assume that the colonies might have been removed from the bottom of the lagoon due to environmental factors, specially the wind.

Although physical and chemical water data were not measured when these samples were collected, we can state that $M$. pulchella occurred both in fresh and brackish water zones of "Peixe" Lagoon, based on the data obtained during other sampling at the same sites. A concentration of $14 \%$ was registered, however, the species was not observed in this sample.
Even though the species was originally described from a freshwater habitat, morphological and metric differences were not observed in the specimens from the brackish water zone. Thus, we can conclude that M. pulchella is able to grow in fresh and brackish waters. Until now, it had been recorded only from a North American lake and its occurrence in a subtropical, southernmost Brazilian ecosystem, expanded the knowledge of the distribution of M. pulchella.

The morphologic and metric characters of the examined specimens are in accordance with those described in Buell (1938) and Komárek \& Anagnostidis (1999). Comparison of M. pulchella with its closest related species (table 1).

The typical polygonal cells of M. pulchella and their dense arrangement in the colonies resemble somehow those of M. granulata (Skuja) Skuja and M. bella (Beck-Mannagetta) Komárek \& Anagnostidis. Nevertheless, the first two species have larger cells. In addition, $M$. granulata has wavy or rolled margin colonies, whereas the colonies of $M$. pulchella are flat, and $M$. pulchella differs from $M$. bella by the absence of conspicuous granules, characteristic of the latter. Besides, according to Komárek \& Anagnostidis (1999), the colonies of $M$. bella have up to 90 cells, whereas the studied material presents about 300 cells.

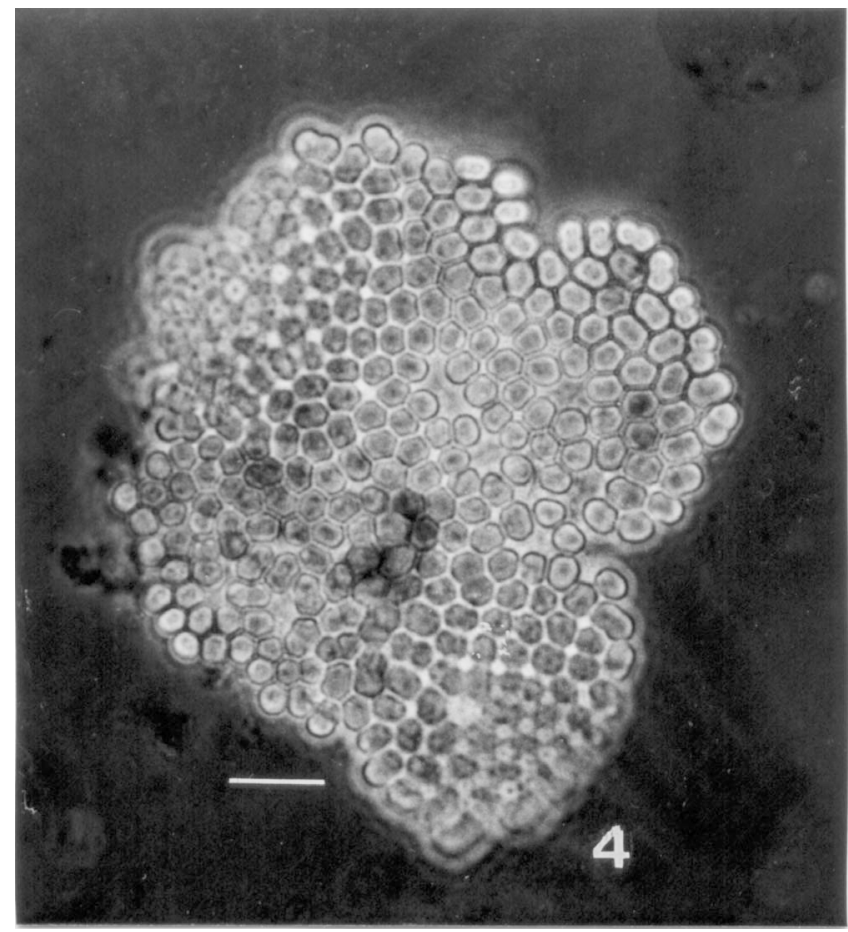

Figure 4. General view of a Microcrocis pulchella (Buell) Geitler colony. Bar $=10 \mu \mathrm{m}$. 


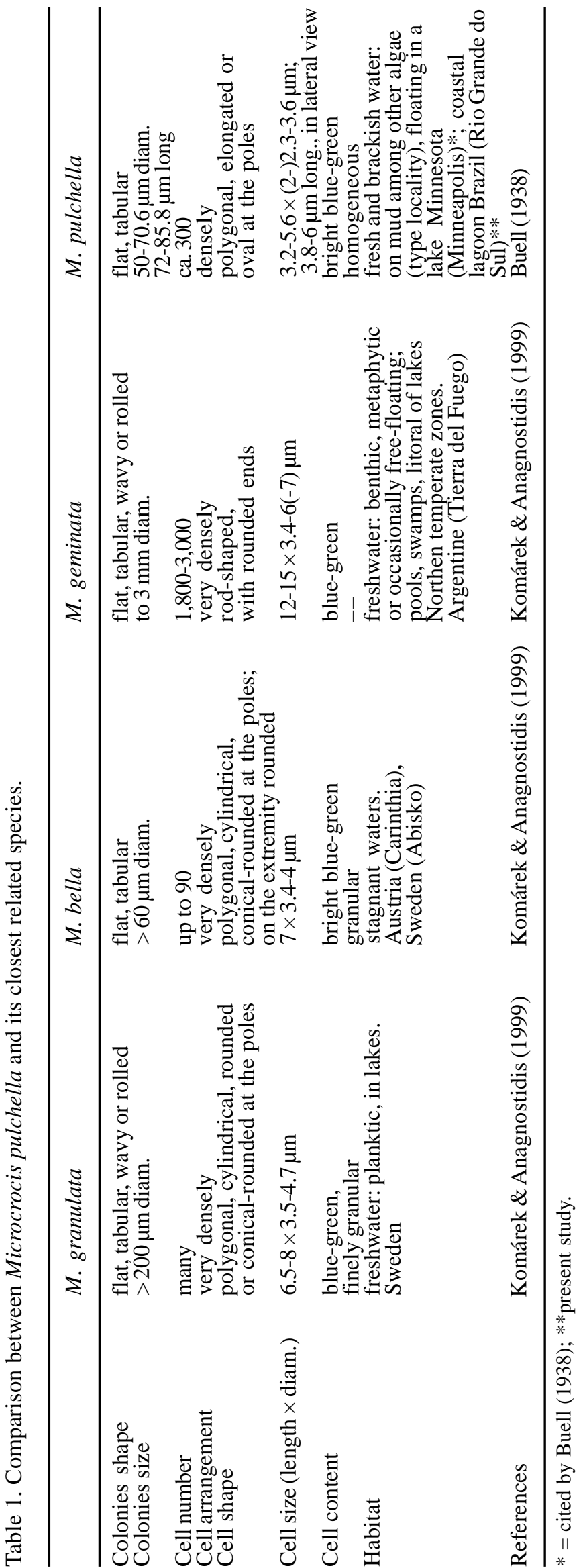

Microcrocis pulchella also resembles M. geminata (Lagerheim) Geitler, especially the specimens described by Richter (1892) and identified as $M$. dietelii Richter, but in this species the cells are larger and rod-shaped with rounded ends, whereas those of $M$. pulchella are polygonal and elongated or oval near the periphery of the colony.

Acknowledgements - To CNPq (National Council of Technological and Scientific Development, Grant Nr. 360149/93-6) for financial support to the first author. To Dr. Jiř́ Komárek for his valuable comments and information, and to both reviewers for their comments and suggestions. To Haywood Dail Laughinghouse IV for reviewing the text, and to Rejane Rosa for preparing the drawings with India ink.

\section{References}

BUELL, H.F. 1938. The taxonomy of a community of bluegreen algae in a Minnesota pond. Bulletin of the Torrey Botanical Club 65: 377-396.

CHOMENKO, L. 1981. Influência da salinidade na distribuição de moluscos do gênero Littoridina na área correspondente ao litoral norte da planície costeira do Rio Grande do Sul. Dissertação de mestrado, Universidade Federal do Rio Grande do Sul, Porto Alegre.

FOTT, B. 1972. On the occurrence and the taxonomy of the genus Microcrocis P. Richter (Cyanophyceae). Preslia 44:97-99.

FRÉMY, P. 1930. Les Myxophycées de l'Afrique équatoriale française. Archives de Botanique. Mémoires 3:1-493.

GEITLER, L. 1932. Cyanophyceae. In Rabenhorst's Kryptogamenflora von Deutschland, Österreich und der Schweiz. (R. Kolkwitz, ed.). Akademische. Verlagsgesellschaft, Leipzig, v.14, p.1-1196.

GEITLER, L. 1942. Schizophyta (Klasse Schizophyceae). In Die natürlichen Planzenfamilien. (A. Engler \& K. Prantl, eds.). W. Engelmann, Leipzig, v.1b, p.1-232.

GUARRERA, S. 1986. Cyanophyta Chroococcales. Buenos Aires: Consejo Nacional de Investigaciones Científicas y Técnicas. v.1, fasc.1, p.1-62p.

KOMÁREK， J. \& ANAGNOSTIDIS， K. 1999. Cyanoprokaryota, 1: Chroococcales. In Süsswasserflora von Mitteleuropa. (H. Ettl, G. Gardner, H. Heynig \& D. Mollenheuer, eds.). Gustav Fischer, Jena, v.19, p.1-548.

LAGERHEIM, G. 1883. Bidrag till Sveriges algflora. Öfversigt af Kongliga Vetenskaps-Akademiens Förhandlingar 40:37-78.

RICHTER, P. 1892. Microcrocis dietelii gen. n. spec. n. In: Phycologia Universalis (F. Hauck \& P. Richter, eds.). FA Brockhaus, Leipzig, fasc.11, p.1-548.

SCHWARZBOLD, A. \& SCHÄFER, A. 1984. Gênese e morfologia das lagoas costeiras do Rio Grande do SulBrasil. Amazoniana 9:87-104. 